\title{
The remnants of restinga habitats in the brazilian Atlantic Forest of Rio de Janeiro state, Brazil: Habitat loss and risk of disappearance
}

\author{
Rocha, CFD. *, Bergallo, HG., Van Sluys, M., Alves, MAS. and Jamel, CE. \\ Departamento de Ecologia, IBRAG, Universidade do Estado do Rio de Janeiro - UERJ, \\ Rua São Francisco Xavier, 524, CEP 20550-013 (ou -011), Rio de Janeiro, RJ, Brazil \\ *e-mail: cfdrocha@uerj.br \\ Received September 20, 2005 - Accepted November 25, 2005 - Distributed May 31, 2007
}

\begin{abstract}
"Restingas" (herbaceous/shrubby coastal sand-dune habitats) used to cover most of Rio de Janeiro State coast, and have suffered extensive degradation over the last five centuries. Using satellite images and field work, we identified the remaining restingas in the State, recording the factors that might cause their degradation. We used two mosaics of Landsat 7 scenes (spatial resolution 15 and $30 \mathrm{~m}$ ) to map and evaluate preliminarly the remaining areas and conservation status. Each remnant area was checked in the field, degraded areas within it were mapped and subtracted from the remnants. We identified 21 restinga remnants totalling 105,285 ha. The largest and smallest restinga remnants were Jurubatiba (25,141 ha) and Itaipu (23 ha), respectively. We identified 14 causes of degradation. The most important were vegetation removal for housing developments, establishment of exotic plant species, change of original substrate, and selective removal of species of economic importance for the horticultural industry. All restingas had disturbed parts under strong pressure due to human activities. Due to intense habitat loss, and occurrence of endemic/threatened vertebrate species in restinga habitats, we strongly indicate the implementation of new conservation units to protect these fragile remnants. This habitat is steadily decreasing and most remnants lack legal protection. Therefore, under the current human pressure most of this unique habitat is likely to be lost from the State within the next few years.
\end{abstract}

Keywords: landscape ecology, conservation, restinga remnants, habitat disturbances, extinction.

\section{Os remanescentes dos hábitats de restinga na Floresta Atlântica do estado do Rio de Janeiro, Brasil: perda de hábitat e risco de desaparecimento}

\begin{abstract}
Resumo
As restingas, que são hábitats de dunas e planícies arenosas cobertas por vegetação herbáceo-arbustiva e que ocorrem na costa do Brasil, no passado cobriam uma grande extensão da costa do Estado do Rio de Janeiro, mas têm sofrido uma extensiva degradação ao longo dos últimos cinco séculos. Utilizando imagens de satélite e mensurações no campo, identificamos os remanescentes de restinga no estado, registrando os fatores que causam sua degradação. Nós utilizamos dois mosaicos de cenas Landsat 7 ( resolução espacial de $15 \mathrm{~m}$ e $30 \mathrm{~m}$ ) para localização e avaliação preliminar do estado de conservação dos remanescentes. Cada remanescente de restinga foi analisado no campo, sendo as áreas degradadas no interior da restinga mapeadas mais detalhadamente e subtraídas da área total do remanescente. Identificamos 21 áreas remanescentes de restinga, totalizando 105,285ha. O maior e menor remanescente de restinga foram Jurubatiba $(25,141$ ha) e Itaipu (23ha), respectivamente. Identificamos 14 fontes de degradação, sendo as mais importantes delas: a remoção da vegetação para desenvolvimento imobiliário, o estabelecimento de espécies vegetais exóticas, a alteração do substrato original e a coleta seletiva de espécies vegetais de interesse paisagístico. Todas as áreas de restinga apresentaram porções com áreas degradadas devido à intensa pressão antrópica. Devido à intensa perda de hábitat e ocorrência de espécies endêmicas e/ou ameaçadas de extinção de vertebrados nas restingas, nós fortemente sugerimos a implementação de novas unidades de conservação para proteger estes frágeis remanescentes. Este tipo de hábitat está continuamente decrescendo e a maior parte dos remanescentes carece de proteção legal. Considerando a atual pressão humana sobre estes ambientes, grande parte deste hábitat é provável ser perdido se não forem tomadas medidas para sua proteção.
\end{abstract}

Palavras-chave: ecologia da paisagem, conservação, remanescentes de restinga, degradação do hábitat, extinção. 


\section{Introduction}

The restingas constitute one of the component habitats of the Atlantic Forest, being the later a "hot spot" in the planet (Myers et al., 2000). These habitats are coastal strips located in coastal lowlands, formed by strings of beaches and sandy dunes covered by herbaceous and arbustive-arboreal vegetation (Araújo, 1992; 2000). In the past, the restingas covered nearly the whole extension of the coast of Rio de Janeiro State (except for the rocky coast) in the Serra do Mar Corridor of biodiversity (Rocha et al., 2003). However, because restingas are located in coastal areas, the intense degradation process resulted in an accentuated alteration and loss of this habitat (Rocha et al., 2004a). The continuous modification of the landscape has resulted in a considerable annual loss of restinga areas due to deforestation (Fundação SOS Mata Atlântica/INPE, 2001). Although preliminary approaches exist on the rate of loss of restinga habitats for the regions of Campos, Ilha Grande, Macaé and Rio de Janeiro city (Fundação SOS Mata Atlântica/INPE/ISA, 1998), all in Rio de Janeiro State, there are still no available detailed quantifications of the totality of the area occupied by remnants of restinga habitats, neither for Brazil nor, on a smaller scale, for Rio de Janeiro State. This state is one of the portions of the Brazilian coast with the highest rate of human occupation and thus its restingas are under one of the highest rates of anthropic pressure, which increases the relevance of obtaining an estimate of the actual area of restinga remnants.

A limitation to the monitoring of the rate of restinga habitat loss is the lack of information about the location and extension of the restinga remnants and about the main degradation factors in each one. Additionally, we also lack information on the conservation state of these remnants to support actions for their protection.

Notwithstanding their extensive presence along the Brazilian coast and despite being located in areas with comparatively high human density, the restingas are still relatively poorly-understood scientifically in several aspects of their biodiversity and state of conservation (Rocha et al., 2004b). Most knowledge about restinga habitats is concentrated in southeastern Brazil but, even in this region, only a few localities such as Maricá and Jurubatiba (in Rio de Janeiro State) and Setiba (in Espírito Santo State) are relatively well-known (Lacerda et al., 1984; Esteves 1998; Esteves and Lacerda, 2000; Rocha et al., 2004b). A great portion of the knowledge on restingas consists of information on their geomorphology (e.g. Bigarella 1965a, b, 1971; Bigarella et al., 1965, 1966; Flexor et al., 1984), limnology (see Esteves, 1998; Esteves and Lacerda, 2000; Farjalla et al., 2001; Rocha et al., 2004b), and vegetation (see Almeida and Araújo, 1997; Araújo and Henriques, 1984; Araújo and Oliveira, 1988; Silva and Somner, 1984; Araújo et al., 1998; Pereira and Araújo 2000; Zaluar and Scarano, 2000; Araújo et al., 2004; Scarano et al., 2004; Rocha et al, 2004b). However, for vertebrate faunas the knowledge is, comparatively, still incipient and restricted (Rocha et al., 2004a). Regarding terrestrial vertebrates, most of the available studies in restingas is about species or communities of reptiles (see overviews in Rocha, 2000; Rocha et al., 2004c) and, on a smaller scale, of amphibians (Britto-Pereira et al., 1988a, b; Carvalho and Silva et al., 2000; Izeckshon and Carvalho and Silva, 2001; Van Sluys et al., 2004), birds (Porto and Teixeira 1984, Alves, 2000; Gonzaga et al., 2000; Alves et al., 2004) and mammals (Cerqueira et al., 1990; 2000; Bergallo et al., 2004). For most restinga habitats, there is not even a vertebrate species list (Rocha et al., 2004b).

Given the current high degree of destruction to which restingas are subject to, one can imagine a scenario in which a great portion of these habitats are being eradicated without us having at least the knowledge on the species composition and of the eventual presence of endemic and threatened species in such areas.

Our concern in the present analysis was to identify the current remnants of restinga habitats in the State of Rio de Janeiro, to provide information on their total area, and to evaluate the main impact factors in each area. With this information it may be possible to monitor the evolution of habitat losses across time and its causes. This can allow the delineation and execution, by the government authorities, of measures for the mitigation of the factors that negatively affect the restinga habitats, augmenting the areas for conservation and/or effectively protecting the existing areas of restinga habitats.

\section{Methodology}

We identified, analyzed and measured the restinga remnants of the State of Rio de Janeiro based on satellite images and through field evaluations in order to estimate the current area of each remnant.

We vectorized polygons involving the restinga areas of the state of Rio de Janeiro, based on interpretations of Landsat 7 images. Four scenes from 2001 to 2002 were used, mosaicked for UTM projection zone 24, with spatial resolution of $15 \mathrm{~m}$, and zone 23, with spatial resolution of $30 \mathrm{~m}$. Both scenes were georreferenced to UTM projection, datum SAD69. The areas of these polygons were calculated (in ha) using the software ArcView. However, because the polygons also included degraded portions of the restingas, we accomplished evaluations in the field to more precisely identify the extension of degraded areas so that they could be subtracted from the estimate of the polygon area. For each restinga remnant identified, we recorded the coordinates of their limits with the use of GPS, registered the main original restinga areas still existing and evaluated the main factors of habitat degradation affecting them locally. Our measures were not restricted to terrestrial habitats. When the restingas included ponds or lagoons, these were included in the estimate of the total area, since these aquatic environments constitute relevant habitats for several restinga species.

In each restinga, the extension of the degraded portions was measured, whenever possible, with the use of 
GPS, and these areas were later subtracted from the total area estimated by imaging. The factors of anthropic degradation identified in each area were registered according to the following categories (Rocha et al., 2003): 1) removal of the vegetation for the construction of highways or coastal avenues or streets; 2) removal of the vegetation for the construction of sidewalks; 3) trampling of the vegetation for access to the beach area of the restinga; 4) removal of the vegetation for the establishment of houses or condominiums; 5) traffic of vehicles on the vegetation or on dunes; 6) removal of the vegetation for the establishment of sports areas (i.e. volleyball, soccer); 7) removal of the vegetation for the establishment of commercial trailers; 8) replacement of the original native vegetation by exotic species (e.g. forest oaks, casuarines, eucalypti, grasses); 9) replacement of the original substrate by other substrates, unfavorable to the original flora (e.g. gravel, sand of thick granulation) along portions of the habitat;10) garbage disposal on the vegetation; 11) burning of portions of the vegetation due to religious practices (e.g. ceremonies of "Umbanda" - a kind of religious culture);12) destruction of the vegetation due to military manoeuvres; 13) selective removal of species of economical interest from the native flora (e.g. bromeliads, orchids).

To be considered as a restinga remnant area in the present study we adpoted as minimum vegetacional criteria an area larger than 1 ha or an area with the occurrence of more than one of the restinga physionomic vegetation zones.

\section{Results and Discussion}

We identified 21 restinga remnants in the state of Rio de Janeiro, totalling $60,516.20$ ha of restinga inserted in a matrix area of 104,095.51 ha, in which several uses of the soil predominate (Table 1). Many restingas, as measured by imaging, were relatively wide (e.g. Massambaba, the area of the Paraíba River delta). However, when these areas were analyzed in the field we found them to be thoroughly altered inside the matrix by several factors of anthropic degradation. These degradation factors were, in most of the cases, not identifiable at the satellite images and considerably reduced the real area estimated as representative of the original restinga. Table 1 shows the remnants of restinga in Rio de Janeiro State, their corresponding municipalities, geographic coordinates, their area (in ha) measured by satellite imaging, the degraded area measured in the field for each restinga and the estimated total area (in ha) of each remnant after excluding those of the degraded portions, the area (in ha) of vegetation recorded as still extant, and the sources of habitat degradation detected in each restinga.

The restingas remaining in the state of Rio de Janeiro are constituted by different-sized fragments, generally surrounded by areas undergoing an accelerated urbanization process. The fragments are generally of small size, with a few exceptions. The largest restinga remnants still present in the state are the Restinga of Jurubatiba
(23,884.8 ha) and the Restinga of the Paraíba River delta, including its northern $(15,437.58 \mathrm{ha})$ and southern (6,949.53 ha) portions (Table 1).

The smallest fragments were the Restinga of Prainha (1.26 ha) where only small patches of halophilous-psammophilous ground vegetation remain and the Itaipu restinga (23 ha), the Restinga of the Parque Chico Mendes (57 ha) and the Restinga of Grumari (143.1 ha) (Table 1).

The field samplings indicated that all restingas have, to a greater or lesser extent, degraded areas within their limits and that all are under intense anthropic occupation pressure.

Generally speaking, we identified 14 sources of degradation negatively affecting the restingas, although each is affected by a particular combination of degradation sources (Table 1). The most important degradation sources detected were the removal of vegetation for the establishment of constructions (houses, condominiums) or highways/walkways (streets, roads, pavements), the removal of vegetation with their replacement by exotic plant species and the change of the original substrate (sand) by other unfavorable ones (e.g. gravel, thick sand) along portions of the habitat and the selective removal of species of economical interest (e.g. bromeliads, orchids, Clusiae).

During the analyses we accomplished by imaging, we identified four areas in the southern portion of the state as potential remnants of restingas (two areas within the district of Paraty, one in Angra dos Reis and one in the region of Mangaratiba). However, our field evaluations indicated that these areas were greatly disturbed and, in their current highly degraded condition, they no longer constitute restinga remnants based on the minimum vegetational criteria considered in the present analysis.

The restinga areas that exist on Ilha Grande (restingas of Praia do Sul and Praia do Leste and that of Lopes Mendes beach) in the municipality of Angra dos Reis are relatively well preserved when compared to the other restingas of the state. This is largely due to their insular character and to the fact that Praia do Sul and Praia do Leste have been legally protected areas since the 1980s (Reserva Biológica da Praia do Sul) (Araújo and Oliveira, 1988).

The restinga of Marambaia is also in a relatively good state of preservation, largely because it is located within a military area, being, thus, of restricted access. On the other hand, it is noteworthy that the frequent action of military manoeuvres and training in the area also cause habitat degradation that is still not easily measurable. Marambaia is an area that should be included prioritarily in the official list of Conservation Units because of the fragility of the habitat itself (it constitutes a narrow vegetated strip of sandbank) and also because of the presence of endemic and/or threatened vertebrate species (e.g. the lizard Liolaemus lutzae, the frog Leptodactylus marambaiae and the bird Mimus gilvus; Araujo and Maciel 1998; Rocha et al., 2003; 2005). 


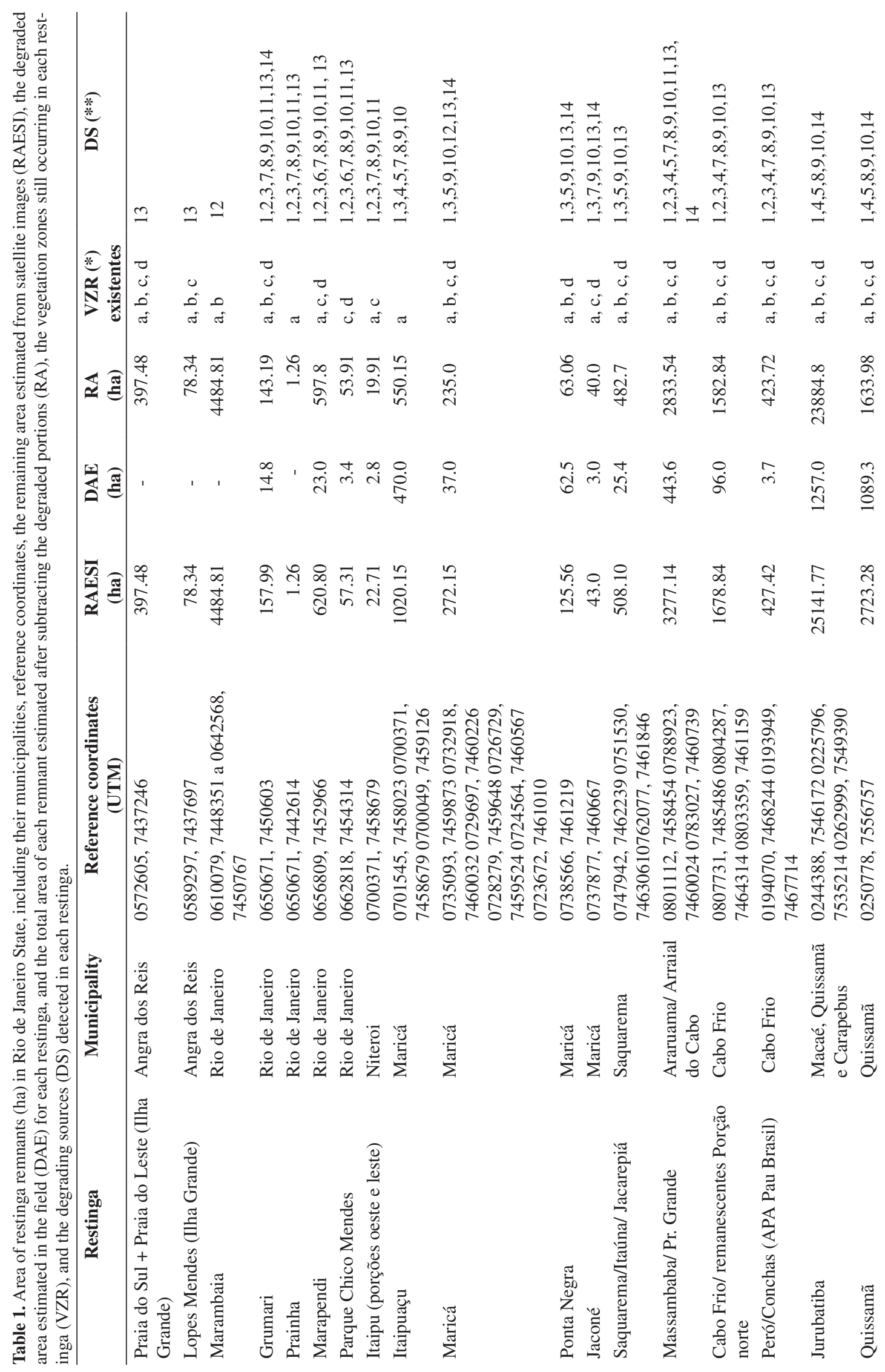




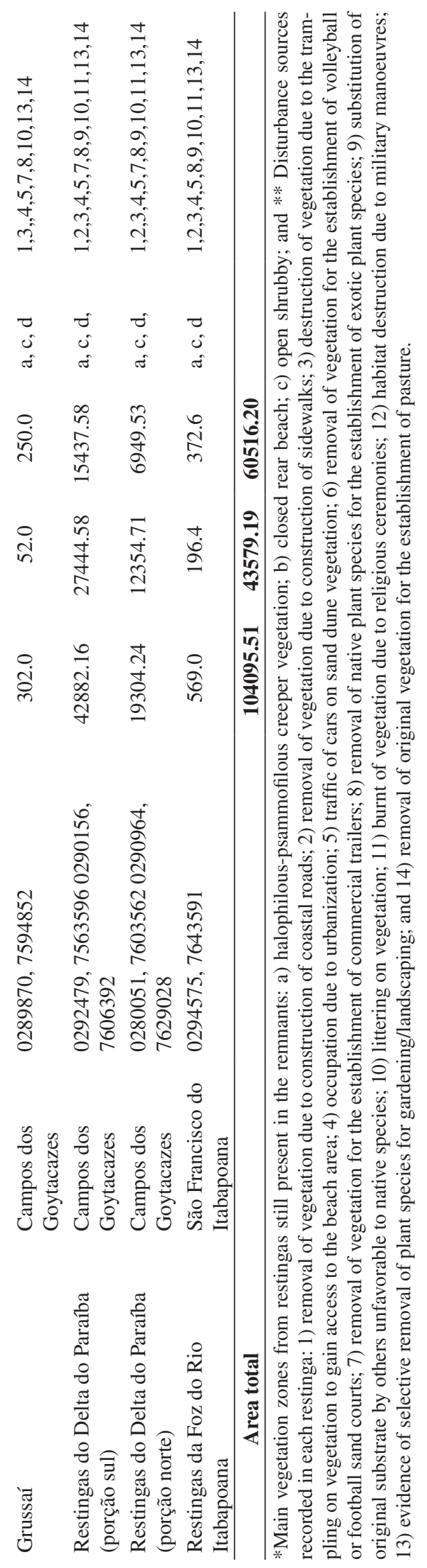


The restinga of Grumari constitutes an area of relevance for being located within the metropolitan area of one of the largest cities of Brazil (Rio de Janeiro), although it is one of the smallest remaining restinga fragments. This restinga is now an Area of Environmental Protection (APA of Grumari), but is nevertheless subject to intense anthropic disturbance. Despite being an APA, the restinga of Grumari has been increasingly degraded by the expansion of farmland and plantation (mainly bananas) areas. This expansion caused considerable loss of the restinga's original area. Although detailed studies are lacking for this area, it includes a few rare/endangered animal species such as an amphisbaenian reptile (Amphisbaena sp.), recently discovered in this restinga, which is being formally described (Barros-Filho, JD., in preparation), and the threatened sand lizard Liolaemus lutzae, which figures on the official List of Threatened Brazilian Fauna (Machado et al., 2005). We strongly recommend that the authorities of Rio de Janeiro city take some action in order to change the category of protection of this restinga from an Area of Environmental Protection to an area of Integral Protection, such as a Biological Reserve.

Prainha, also in Rio de Janeiro city, is the smallest area with remaining restinga vegetation (only $1.26 \mathrm{ha}$ ). In this area there are currently only small patches of beach vegetation (halophilous-psammophilous ground vegetation).

In Barra of Tijuca, Rio de Janeiro city, there are two restinga remnants (Restingas of Marapendi and of the Parque Chico Mendes) which, although being of small dimensions, are of special relevance for being within the metropolitan area of Rio de Janeiro. These two areas have been turned into Conservation Units (APAs of the Ecological Municipal Park of Marapendi and Ecological Municipal Park Chico Mendes) but not as areas of integral protection which, due to the intense degradation pressure of the surrounding area, still makes them fragile habitats.

In Itaipu, Niterói city, most of the restinga was destroyed due to urbanization. The remnant restinga is covered by patches of halophilous-psammophilous ground vegetation along the beach and arbustive restinga vegetation covering the so-called Duna Grande and Duna Pequena (both remnant sand dunes and archeological sites). Also, there are some humid areas west of Itaipu Lagoon, covered by restinga marsh and mangrove vegetation. The restinga of Itaipu area is at present considerably threatened by high income urbanization projects.

In Maricá municipality, the remaining restinga areas are in a state of great degradation, except for the vegetated area off the west of Barra of Maricá, which is still in a relatively good state of preservation. This area, which is still not included in the list of Conservation Units, is inhabited by endemic and/or threatened species (such as the treefrog Xenohyla truncata and the lizards Liolaemus lutzae and Cnemidophorus littoralis; Britto-Pereira et al., 1988a,b; Rocha, 2000a,b). The tropical mocking- bird, Milmus gilvus, has not been recorded on this site since 1985 and Gonzaga et al. (2000) and Alves et al. (2004) suggested this species might already be locally extinct in the Maricá restinga. We strongly recommend that the remnant of the Barra of Maricá Restinga be included in the list of protected areas (SNUC) as an area of Integral Protection to avoid the loss of one of the most significant restinga remnants in the State of Rio de Janeiro and of its important fauna and flora elements. The other remaining areas of restinga in Maricá municipality (Itaipuaçu, Ponta Negra and Jaconé) are already considerably degraded, with just a few small portions remaining amid a matrix altered by irregular occupation of the soil. In Jaconé we identified a small remnant of restinga forest of approximately 40 ha (approximate coordinates $22^{\circ} 56^{\prime} 48.1^{\prime \prime} \mathrm{S}$ and $42^{\circ} 40^{\prime} 13.4$ " W) which, because of its good preservation state, should be protected by the municipal authorities. In all areas of Maricá municipality the problems underlying the removal of the restingas are similar, the most outstanding being the parcelling of the soil for construction of small housing units, the construction of condominiums and the increasing occurrence of slums. In all restinga areas in Maricá, garbage disposal on the remaining vegetation is a usual practice.

The municipal district of Saquarema has outstanding differences in terms of the conservation of its restingas between the western and eastern portions. The western portion, locally denominated Nova Barra, has been thoroughly destroyed after the removal of the restinga vegetation for urbanization purposes that, visibly without planning, allowed the occupation of the whole area by properties, which extend close up to the beach. Even the beach vegetation (halophilous-psammophilous ground vegetation) has been removed for the construction of roads, which may reduce the capacity of fixation of the dunes. As a consequence, this coastal road now suffers serious problems related to the constant accumulation of sand on the highway and to the collapse of highway passages due to the mechanical action of the sea waves, during periods of high tide. In the few remaining patches of sand vegetation still existent in Nova Barra and Jaconé, individuals of the sand lizard Liolaemus lutzae are still found. In the few remaining small patches of restinga vegetation near the beach in Jaconé, the threatened bird Formicivora littoralis can still be found. However, these patches are surrounded by properties and some of them are already for sale (Vecchi and Alves, no prelo). This is the only bird species endemic both to restinga habitats and to the State of Rio de Janeiro (Gonzaga and Pacheco, 1990).

The eastern portion of Saquarema municipality (to the east of Itaúna Beach), an area close to the Jacarepiá Reserve, is in a comparatively better state of conservation, with an important remaining patch of restinga in good condition. However, this area suffers from relevant impacts such as the constant traffic of vehicles (especially buggies) on the sand dunes and beach vegetation, garbage dumping and removal of some plant species for 
commercial purposes (mainly bromeliads and orchids). It is advisable that special attention be given by the authorities of Saquarema city council to this important restinga remnant (Jacarepiá), so as to mitigate the negative factors now existent and to promote the protection of this area. This is an important area where the threatened lizard Liolaemus lutzae, and the frog Xenohyla truncata, both endemic to restingas in the State of Rio de Janeiro, are found (Rocha et al, 2003; 2005). This restinga is also included in the distribution area of the threatened bird Formicivora littoralis by Gonzaga and Pacheco (1990), who suggested that the distribution area of this bird species was from Saquarema municipality to Peró beach in Cabo Frio municipality and adjacent islands. Its occurrence in the area was recently confirmed by Vecchi and Alves (no prelo).

The restinga to the east of Jacarepiá, in Saquarema, which extends to Arraial do Cabo (including the whole area of the restinga of Massambaba), is under extensive destruction due to the excessive parceling of the soil (small units in masonry from 30 to $80 \mathrm{~m}^{2}$ ), the irregular occupations, the wide expansion of properties without appropriate planning, the considerable number of slum cells and the constant garbage dumping on the vegetation. This soil occupation model which causes the destruction of the restinga habitat is critical in that area, especially in the restinga of Pernambuca beach in Arraial do Cabo. In the shoreline area, close to the local village, even the beach vegetation has been almost totally removed by the intense proliferation of slums, by the construction of roads and irregular condominiums and by the establishment of trailers. In this area we still find the lizard Liolaemus lutzae and the bird Formicivora littoralis. This species was mentioned by Collar et al. (1992) as threatened due to the increasing real-estate speculation along its distribution area. Another bird also recorded in this area was Mimus gilvus (M.B. Vecchi, personal obs.), a species considered threatened in Rio de Janeiro State (Alves et al. 2000). It is urgent that the irregular occupation of these areas be halted and areas of protection of the restinga of Massambaba be demarcated. It is important to promote a sustainable use of the soil in the area that compatibilizes the needs of urban occupation with the protection of the restinga remnants and of the lagoon systems.

In the region of Cabo Frio, all remnants are of small dimensions (restingas of the northern portion of the municipality, of Praia do Foguete, of Praia do Forte and of the beaches of Peró/Conchas - APA of Pau Brasil), are thoroughly fragmented and are now isolated amid a matrix of intense urbanization process. In those areas, remaining populations of the lizard Liolaemus lutzae and of the bird Formicivora littoralis are still found. These restingas are being destroyed due to the construction of buildings, roads and pavements, and due to the erection of commercial establishments (e.g. trailers) and to the trampling of the vegetation.
The restinga of Jurubatiba, in the northern part of the State of Rio de Janeiro, is one of the state's (and of Brazil's) largest areas of restinga, especially if we consider only those under effective protection (Rocha et al., 2002; 2004a). This restinga has an area of about 23,000 ha, of which 14,860 ha are in very good state of conservation. This restinga encompasses the municipalities of Macaé, Carapebus and Quissamã, extending for approximately $44 \mathrm{~km}$ along the coast and varying from 2 to $4 \mathrm{~km}$ in width. Ten different types of vegetation profile occur there: the halophilous-psammophilous ground vegetation of the dunes and beach area, the closed arbustive "post-beach" vegetation, the open restinga of Clusia, the open restinga of Ericaceae, the periodically flooded restinga forest, the permanently flooded restinga forest, the "sandy string" forest, the open arbustive vegetation of Palmae, the grassy formation with bushes (swampy herbaceous) and the aquatic vegetation of the ponds and lagoons (Araújo et al., 1998; Esteves, 1998; Esteves and Lacerda, 2000; Araújo et al., 2004). the different formations along this area provide suitable habitats for a great range of organisms, including migratory and resident bird species (Alves et al., 2004) and endemic and/or threatened species of amphibians and reptiles (Van Sluys et al., 2004; Rocha et al., 2004b; Rocha et al., 2005. It should be emphasized that among restingas, Jurubatiba is one of the restingas with one of the richest and most diverse mammal faunas (Bergallo et al., 2004). In 1998, the restinga of Jurubatiba was converted into a Conservation Unit of Integral Protection (Restinga de Jurubatiba National Park - PNRJ). The creation of the PNRJ was fundamental to the effective conservation of one of the largest continuous remnants of restinga in the State of Rio de Janeiro. The Park protected the several types of habitats of the restinga, its biological diversity and the endemic and/or threatened species living there, such as the teiid lizard Cnemidophorus littoralis (Rocha et al., 2004a,b; 2005), the bufonid anuran Bufo pygmaeus (Van Sluys et al. 2004; Rocha et al., 2005), the tropical mockingbird Mimus gilvus (Alves et al., 2004; Rocha et al., 2005), the wild duck Cairina moschata (Alves, MAS., personal obs.) and the spiny rat Trinomys eliasi (Bergallo et al., 2004), considered threatened in the State of Rio de Janeiro (Bergallo et al., 2000). In this restinga, in the last six years, after the establishment of a "Long-Term Ecological Researches Program" (PELD/ $\mathrm{CNPq}$ ), several scientific studies have been undertaken (Rocha et al. 2004c), which has provided a basis for the management and conservation of its biological communities.

The restingas of Grussaí, Quissamã, the Paraíba River Delta and the Itabapoana River mouth are all under similar processes of eradication due to the continuous urbanization and to the substitution of restingas by cultivated areas. Fieldwork in those areas has shown that agriculture is one of the most relevant factors removing the restinga vegetation. In several areas we detected irregular urbanization processes in which the 
establishment of slums prevailed. In the southern portion of Grussaí, close to the center of the county seat, there is a restinga remnant (approximate coordinates $21^{\circ} 43^{\prime} 86.6$ " $\mathrm{S}$ and $41^{\circ} 01$ ' $53.5 " \mathrm{~W}$ ) which, although small, is important because it is in a relatively good state of conservation and is home to a dense population of the endemic and threatened lizard Cnemidophorus littoralis (Rocha et al, 2005).

In the area around the Paraíba River delta field analyses indicated that the extensive areas still covered by restinga vegetation are not in a good state of conservation. There, the intense soil exploitation for different uses (pasture areas, planting of coconut trees, clearings, eucalyptus plantations), results in a mosaic of different uses of the soil among which are extensive patches of original restinga vegetation. As a result, the satellite images of these areas may be misleading because the loss of the restinga habitats can only be accurately noticed in the field. Our field estimates indicated a loss of approximately $50 \%$ of the restinga vegetation cover in the Paraíba River delta (Table 1).

Two first studies of the current conservation effort of the restingas in Rio de Janeiro State can be found in Rocha et al. (2003) and in Rocha et al. (2004a). Those studies showed that, considering the total extension of the coastline of Rio de Janeiro State, relatively few areas of restinga are officially within Conservation Units (CUs). Among the ones that constitute a CU, only two are considered as areas of integral protection: the National Park of the Restinga of Jurubatiba (14,860 ha) and the Biological Reserve of Praia do Sul, in Ilha Grande (3,600 ha), totalling 18,460 ha of protected restinga habitat (SEMA, 2001). There are still another five CUs of sustainable usage established in restinga areas (APAs of Grumari - 951 ha, of Prainha - 166 ha, of Maricá - 500ha, of Massambaba - 7,630.60 ha and of the Pau Brasil 9,247.60 ha (SEMA, 2001; IBAM/DUMA/ PCRJ/SMAC, 1988). Rocha et al. (2003, 2004a) pointed out that, although these APAs are areas of high biological importance, a Director Plan and the effectivation of protection measures are missing. The creation of the Ecological Reserves of Massambaba and of Jacarepiá was indicated by the State Foundation of Engineering and Environment (FEEMA) and by the State Institute of Artistic and Cultural Patrimony (INEPAC) for the restinga of Massambaba, due to its importance for the conservation of biodiversity. However, they have not yet been executed (SEMA, 2001). The effectivation of these CUs must be urgently accomplished.

To sum up, in the present analysis we detected that, in general, the restinga areas of Rio de Janeiro State are under intense degradation pressure that is causing the loss of extensive portions of this habitat at an accelerated pace. Based on our results, the most critical situations in terms of degradation pressure (and consequent habitat loss) seem to be those of the restingas of Jaconé, Massambaba, Arraial do Cabo, Grussaí, the one of Paraíba River Delta and the one of the Itabapoana
River mouth. Due to the lack of monitoring programs to analyze the evolution of the cover area of this habitat type, the actual rate of loss of the restinga areas in Rio de Janeiro State is still unknown. For this reason we recommend the establishment of medium to long-term monitoring programs for the restingas, across an ample geographic scale.

Additionally, due to the current intense and accelerated loss rate of restinga habitats, coupled with the occurrence of endemic and threatened species, we strongly recommend that new Conservation Units of Integral Protection be created in order to protect these fragile remnants. Besides creating new CUs, it is also highly important to keep them effectively protected. It is also urgent to effectively protect two of the already-created CUs: Jacarepiá and Massambaba. The public authorities of each municipal district should map all of the remaining fragments of restinga within their political-geographical limits aiming to protect those in good condition, regardless of their size. Although almost all of the coast of Rio de Janeiro State was covered by restinga habitats in the past, nowadays the area covered by this type of habitat of the Atlantic forest is decreasing at an alarming rate. If effective protection measures of restingas are not taken by the authorities (both at the State and municipal levels), great portions of this habitat type (and of the species that depend on it) may disappear from the State of Rio de Janeiro in the near future.

Acknowledgments - This study is a portion of the results of the "Programa de Ecologia, Conservação e Manejo de Ecossistemas do Sudeste Brasileiro" of the Departmento de Ecologia, Instituto de Biologia, Universidade do Estado do Rio de Janeiro, in partnership with Instituto de Pesquisas e Conservação dos Biomas Brasileiros - Instituto Biomas. This study was supported by a grant from the Conservation Biodiversity Center- CBCMata Atlântica of Conservation International Brazil. This study was also partially supported by grants conceded to the first four authors, respectively, from the Conselho Nacional do Desenvolvimento Científico e Tecnológico $(\mathrm{CNPq}$ - Processes 307653/2003-0, 302405/02-0, 462003/00-0 and 477981/03-8, 302718/03-6) and from Fundação de Amparo à Pesquisa do Estado do Rio de Janeiro (FAPERJ). We especially thank all our students for field assistantship in the restinga areas that we have studied in the past years. D. Vrcibradic, T. P. Moulton and D. Gettinger kindly revised the manuscript offering helpful suggestions.

\section{References}

ALMEIDA, AL. and ARAÚJO, DSD., 1997. Comunidades vegetais do cordão arenoso externo da Reserva Ecológica Estadual de Jacarepiá, Saquarema, RJ. Oecologia Brasiliensis, vol. 3, p. 47-63.

ALVES, MAS., 2000. Sistemas de acasalamento em Aves: as restingas como ambientes apropriados para estudo. Em: Ecologia de Restingas e Lagoas Costeiras. ESTEVES, FA. and LACERDA, LD. (eds) . Rio de Janeiro: Computer \& Publish Editoração Gráfica. Núcleo de Pesquisas Ecológicas de Macaé (NUPEM/UFRJ), vol. 1, p. 179-188. 
ALVES, MAS., PACHECO, JF., GONZAGA, LAP., CAVALCANTI, RB., RAPOSO, MA., YAMASHITA, C., MACIEL, NC. and CASTANHEIRA, M., 2000. Aves. Em: $A$ Fauna Ameaçada de Extinção do Estado do Rio de Janeiro. BERGALLO, HG., ROCHA, CF., ALVES, MA. and VAN SLUYS, M. (Eds.) Rio de Janeiro: EdUERJ, p. 113-124.

ALVES, MAS., STORNI, A., ALMEIDA, EM., GOMES, VSM., OLIVEIRA, CHP., MARQUES, RV. and VECCHI , MB. p. 199-214. Em: ROCHA, CFD., ESTEVES, FA. and SCARANO, FR. 2004. Pesquisas Ecológicas de Longa Duração na Restinga de Jurubatiba. Ecologia, História Natural e Conservação. Editora Rima, Sao Carlos, 2004, p. 376.

ARAÚJO, D. and OLIVEIRA, R., 1988. Reserva Biológica Estadual da Praia do Sul (Ilha Grande, Rio de Janeiro): lista preliminar da flora. Acta bot. bras., vol. 1, no. 2, p. 83-94.

ARAÚJO, DSD., 1992. Vegetation types of sandy coastal plains of Tropical Brazil: A first approximation. In SEELIGER, U. (ed.). Coastal plant communities of Latin America. Academic Press, New York, p. 392.

-, 2000. Análise florística e fitogeográfica das restingas do Estado do Rio de Janeiro. (Tese de Doutorado) - Departamento de Ecologia, Universidade Federal do Rio de Janeiro, Rio de Janeiro, p. 169.

ARAÚJO, DSD. and MACIEL, NC., 1998. Restingas fluminenses: biodiversidade e preservação. Boletim da FBCN. vol. 25 , p. 27-51.

ARAÚJO, DSD. and HENRIQUES, RPB., 1984. Análise florística das restingas do Estado do Rio de Janeiro. Em: Restingas, Origem, Estrutura e Processos. LACERDA, LD., Araújo, DSD., CERQUEIRA, R. and TURCQ, B. (orgs.). Centro Editorial da Universidade Federeal Fluminense, Niterói, RJ, p. 327-342.

ARAÚJO, DSD. and OLIVEIRA, RR., 1988. Reserva Biológica Estadual da Praia do Sul (Ilha Grande, Estado do Rio de Janeiro): Lista preliminar da flora. Acta Botanica Brasilica, vol. 1, no. 2, p. 83-94 (suplemento).

ARAÚJO, DSD., SCARANO, FR., SÁ, CFC, KURTZ, BC., Zaluar, HLT., MONTEZUMA, RCM. and OLIVEIRA, RC., 1998. As comunidades vegetais do Parque Nacional da Restinga de Jurubatiba, Macaé, RJ. Em: ESTEVES, F.A. (Ed.). Ecologia das lagoas costeiras do Parque Nacional da Restinga de Jurubatiba e do Município de Macaé (RJ). NUPEM / UFRJ, p. 39-62.

ARAÚJO, DSD., PEREIRA, MCA. and PIMENTEL, MCP., 2004. Flora e Estrutura de Comunidades na Restinga de Jurubatiba - Sintese dos conhecimentos com enfoque especial para a formacao aberta de Clusia. p. 59-76 Em: Pesquisas Ecologicas de Longa Duracao na Restinga de Jurubatiba. Ecologia, História Natural e Conservação. Editora Rima, São Carlos, 376p. Editora Rima, São Carlos, p. 376.

BERGALLO, HG., ROCHA, CFD., ALVES, MAS. and VAN SLUYS, M., (Orgs.). A Fauna Ameaçada de Extinção do Estado do Rio de Janeiro, 2000, p. 166, EDUERJ, Rio de Janeiro.

BERGALlO, HGF., MARTINS-HATANO, DS., RAÍCES, TTL., RIBEIRO, AG., ALVES, JL., LUZ, R., MANGOLIN and MELLO, MAR., 2004. Os mamíferos da Restinga de Jurubatiba, pp. 215-232. Em: ROCHA, C. F. D., F. A. ESTEVES \& F. R. SCARANO. 2004. Pesquisas Ecológicas de Longa Duração na Restinga de Jurubatiba. Ecologia, Historia Natural $e$ Conservação. Editora Rima, Sao Carlos, p. 376.

BIGARELLA, JJ., 1965a. Subsídios para o estudo de variações de nível oceânico no Quaternário brasileiro. An. Acad. Bras. Ciênc., vol. 37, p. 263-278.

-, 1965b. Sand-ridge structures from Paraná Coastal Plain. Marine Geology, vol. 3, p. 269-278.

-, 1971. Variações climáticas no Quaternário superior do Brasil e sua datação radiométrica pela datação do carbono 14 . Paleoclimas, vol. 1, p. 1-22.

BIGARELLA, JJ., MOUSINHO, MR. and SILVA, JX., 1965. Pediplanos, pedimentos e seus depósitos correlativos no Brasil. Bol. Parana Geogr., vol. 16/17, p. 117-151.

BIGARELLA, JJ., FREIRE, SS., SALAMUNI, R. and VIANA, R., 1966. Contribuição ao estudo dos sedimentos praiais recentes II. Praias de Matinhos e Caiobá. Universidade Federal do Paraná, Geol. Física 6, supl. 1-109.

BRITTO-PEREIRA, MC., CERQUEIRA, R., SILVA, HR. and CARAMASCHI, U., 1988a. Anfíbios anuros da restinga de Maricá - RJ: levantamento e observações sobre a atividade reprodutiva das espécies registradas. An. Sem. Reg. São Carlos, vol. 6, p. 295-306.

-, 1988b. Utilização de Neoregelia cruenta (Bromeliaceae) como abrigo diurno por anfíbios anuros na restinga de Maricá - Rio de Janeiro. An. Sem. Reg. São Carlos, vol. 6, p. 307-318.

CARVALHO e SILVA, SP., IZECKSOHN, E. and CARVALHO e SILVA, AMPT, 2000. Diversidade e ecologia de anfíbios em restingas do sudeste brasileiro. Em: Ecologia de Restingas e Lagoas Costeiras. ESTEVES, FA. and LACERDA, LD. (eds.), p. 89-97. Macaé: NUPEM/UFRJ.

CERQUEIRA, R., 2000. Biogeografia das Restingas. In ESTEVES, FA. and LACERDA, LD. (eds), vol. 1, p. 65-75. Rio de Janeiro: Computer \& Publish Editoração Gráfica. Núcleo de Pesquisas Ecológicas de Macaé (NUPEM/UFRJ).

CERQUEIRA, R., FERNANDEZ, FAS. and NUNES, MFQS., 1990. Mamíferos da restinga de Barra de Maricá. Pap. Avuls. Zool. São Paulo, vol. 37, p. 141-157.

COLLAR, NJ., GONZAGA, LP., KRABBE, N., MADROÑO, A., NIETO, LG., NARANJO, TA., PARKER III and WEGE, DC., 1992. Threatened birds of the Americas: The ICBP/IUCN Red Data Book. International Council for Bird Preservation, Cambridge, U.K., p. 1150.

ESTEVES, FA., 1998. (ed.). Ecologia das lagoas costeiras do Parque Nacional da Restinga de Jurubatiba e do Município de Macaé $(R J)$. Núcleo de Pesquisas Ecológicas de Macaé (NUPEM/UFRJ), p. 442p.

ESTEVES, FA. and LACERDA, L.D., 2000. Ecologia de Restingas e Lagoas Costeiras. Computer \& Publish Editoração Gráfica. Núcleo de Pesquisas Ecológicas de Macaé (NUPEM/ UFRJ), p. 394.

FARJALLA, VF., FARIA, BM., ESTEVES, FA. and BOZELLI, R., 2001. Bacterial density and biomass and relations with abiotic factors in 14 coastal lagoons of Rio de Janeiro State. pp 65-76 In FARIA, B.M., V. F. FARJALLA and F.A. ESTEVES (eds.). Aquatic microbial Ecology in Brazil. Series Oecologia Brasiliensis, vol IX. PPGE-UFRJ, Rio de Janeiro, RJ, p. 216. 
FLEXOR, JM., MARTIN, L., SUGUIO, K. and DOMINGUEZ, JML., 1984. Gênese dos cordões litorâneos na parte central da costa brasileira. Em: Restingas: origem, estrutura e processos. LACERDA, LD., ARAUJO, DSD, CERQUEIRA, R. and TURCQ, B. (eds.)., Centro Editorial da Universidade Federal Fluminense, CEUFF, Niterói, Rio de Janeiro, p. 35-45.

FUNDAÇÃO SOS MATA ATLÂNTICA/INPE. 2001. Atlas dos remanescentes florestais do Rio de Janeiro.

-, 1998. Atlas da evolução dos remanescentes Florestais da Mata Atlântica e ecossistemas associados no período de 1990-1995. São Paulo, 1998.

GONZAGA LP. and PACHECO, JF., 1990. Two new subspecies of Formicivora serrana (Hellmayr) from southeastern Brazil, and notes on the type locality of Formicivora deluzae Ménétriés. Bull. B.O.C., vol. 110, no. 4, p. 187-193.

GONZAGA, LP., CASTIGLIONI, GDA. and REIS, HBR., 2000. Avifauna das Restingas do Sudeste: estado do conhecimento e potencial para futuros estudos. Em: Ecologia de Restingas e Lagoas Costeiras. ESTEVES, FA. and LACERDA, LD. (eds) vol. 1, Rio de Janeiro: Computer \& Publish Editoração Gráfica. Núcleo de Pesquisas Ecológicas de Macaé (NUPEM/UFRJ), p. $179-188$.

IBAM/DUMA/PCRJ/SMAC., 1998. Guia das Unidades de Conservação Ambiental do Estado do Rio de Janeiro. Rio de Janeiro: Prefeitura Municipal do Rio de Janeiro, Secretaria Municipal do Meio Ambiente, Instituto Brasileiro de Administração Municipal, Superintendência de Desenvolvimento Urbano e Meio Ambiente, p. 208.

IZECKSHON, E. and CARVALHO e SILVA, SP., 2001. Anfíbios do Município do Rio de Janeiro. Editora UFRJ, Rio de Janeiro, p. 147.

LACERDA, LD., ARAÚJO, DSD., CERQUEIRA, R., 1984. and TURCQ, B. Restingas: Origem, Estrutura e Processos. Centro Editorial da Universidade Federeal Fluminense, Niterói, RJ.

MACHADO, ABM., MARTINS, CS. and DRUMMOND, GM., 2005. Lista da Fauna Brasileira Ameaçada de Extinção: incluindo as espécies quase ameaçadas e deficientes em dados. Fundação Biodiversitas, Belo Horizonte, p. 160.

MYERS, N, MITTERMEIER, RA., MITTERMEIER, CG., FONSECA, GA. and KENT, J., 2000. Biodiversity hotspots for conservation priorities. Nature, vol. 403, no. 24, p. 853-858.

PEREIRA, OJ. and ARAÚJO, DSD., 2000. Análise florística das restingas dos estados do Espírito Santo e Rio de Janeiro. In ESTEVES, FA. and LACERDA, LD. (eds) vol. 1, p. 25-63. Rio de Janeiro: Computer \& Publish Editoração Gráfica. Núcleo de Pesquisas Ecológicas de Macaé (NUPEM/UFRJ).

PORTO, FCS. and TEIXEIRA, DM., 1984. Um estudo comparativo preliminar sobre as avifaunas das restingas do leste do Brasil. Em: Restingas, Origem, Estrutura e Processos. LACERDA, LD., ARAÚJO, DSD., CERQUEIRA, R. and TURCQ, B. (orgs.), p. 343-350. Centro Editorial da Universidade Federeal Fluminense, Niterói, RJ.

ROCHA, CFD., 2000. Biogeografia de répteis de restinga: distribuição, ocorrência e endemismos. ESTEVES, FA. and LACERDA, LD. (eds) vol. 1, p. 99-116. Rio de Janeiro:
Computer \& Publish Editoração Gráfica. Núcleo de Pesquisas Ecológicas de Macaé (NUPEM/UFRJ).

ROCHA, CFD., ARAÚJO, AFB., VRCIBRADIC, D. and MAMEDE-DA-COSTA, EM. 2000b. New Cnemidophorus (Squamata; Teiidae) from coastal Rio de Janeiro, southeastern Brazil. Copeia 2000: 501-509. OBS - no texto detectado apenas Rocha 2000.

ROCHA, CFD., BERGALLO, HG., ALVES, MAS. and VAN SLUYS, M., 2002. O estado da biodiversidade nos grandes blocos de remanescentes florestais no Estado do Rio de Janeiro e nas restingas dos corredores da Serra do Mar e Central da Mata Atlântica. Relatório Técnico, Departamento de Ecologia, Instituto de Biologia, Universidade do Estado do Rio de Janeiro/ Conservation International do Brasil, p. 116.

-, 2003. A Biodiversidade nos Grandes Remanescentes Florestais do Estado do Rio de Janeiro e nas Restingas da Mata Atläntica. Instituto Biomas \& Conservation International Brasil, Editora Rima, p. 160.

-, 2004a. A Restinga de Jurubatiba e a Conservação dos ambientes de restinga do Estado do Rio de Janeiro, p. 341352. Em: ROCHA, CFD., ESTEVES, FA. and SCARANO, FR. 2004. Pesquisas Ecológicas de Longa Duração na Restinga de Jurubatiba. Ecologia, História Natural e Conservação. Editora Rima, São Carlos, 376p. Editora Rima, São Carlos, p. 376.

ROCHA, CFD., VAN SLUYS, M., VRCIBRADIC, D., HATANO, FH., GALDINO, CAC., CUNHA-BARROS, M. and KIEFER, MC., 2004b. p. 179-198. A comunidade de répteis na restinga de Jurubatiba. Em: ROCHA, CFD., ESTEVES, FA. and SCARANO, FR. 2004. Pesquisas Ecológicas de Longa Duraçaão na Restinga de Jurubatiba. Ecologia, História Natural e Conservação. Editora Rima, Sao Carlos, p. 376.

ROCHA, CFD., ESTEVES, FA. and SCARANO, FR., 2004c. Pesquisas Ecológicas de Longa Duração na Restinga de Jurubatiba. Ecologia, História Natural e Conservação. Editora Rima, São Carlos, p. 376.

ROCHA, CFD., VAN SLUYS, M., BERGALLO, HG. and ALVES, MAS., 2005. Endemic and threatened tetrapods in the restingas of the biodiversity corridors of Serra do Mar and of the Central da Mata Atlântica in eastern Brazil. Braz. J. Biol. vol. 65 , no. 1 , p. $159-168$.

SCARANO, FR, CIRNE, P., NASCIMENTO, MT., SAMPAIO, MC., VILLELA, DM., WENDT, T. and ZALUAR, HLT., 2004. Ecologia vegetal: Integrando Ecossistema, Comunidades, Populações e Organismos, p. 77-97 in Pesquisas Ecologicas de Longa Duração na Restinga de Jurubatiba. Ecologia, Historia Natural e Conservação. Editora Rima, São Carlos, p. 376.

SEMA., 2001. Atlas das Unidades de Conservação da Natureza do Estado do Rio de Janeiro. Secretaria de Estado de Meio Ambiente e Desenvolvimento Sustentável, Governo do Estado do Rio de Janeiro, Rio de Janeiro Metalivros, p. 48.

SILVA, JG. and SOMNER, GV., 1984. A vegetação da restinga de Maricá. Em: Restingas, Origem, Estrutura e Processos. LACERDA, LD., ARAÚJO, DSD., CERQUEIRA, R. and TURCQ, B. (orgs.). Centro Editorial da Universidade Federal Fluminense, Niterói, RJ, p. 285-304.

VAN SLUYS, M., ROCHA, CFD., HATANO, FH., BOQUIMPANI-FREITAS, L. and MARRA, RV., 2004. Anfíbios 
da restinga de Jurubatiba: composição e história natural, p. 165178. Em: ROCHA, CFD., ESTEVES, FA. and SCARANO, FR. 2004. Pesquisas Ecologicas de Longa Duracao na Restinga de Jurubatiba. Ecologia, Historia Natural e Conservação. Editora Rima, Sao Carlos, p. 376.

VECCHI, MB. and ALVES, MAS., 2008. New records of the Restinga antwren Formicivora littoralis (Aves, Thamnophilidae) in the state of Rio de Janeiro, Brazil: inland extended range and threats. Brazilian Journal of Biology, No prelo, vol. 68, no. 4.

ZALUAR, HLT. and SCARANO, FR., 2000. Facilitação em restingas de moitas: Um século de buscas por espécies focais. In ESTEVES, FA. and LACERDA, LD. (eds), Ecologia de restingas e Lagoas Costeiras, vol. 1, p. 03-23. Rio de Janeiro: Computer \& Publish Editoração Gráfica. Núcleo de Pesquisas Ecológicas de Macaé (NUPEM/UFRJ). 
